From the classics of Altaic and Turkic studies -

Алтаистика және түркітану классикасынан Из классики алтаистики и тюркологии

\title{
The monuments of architecture of Oyrat-Kalmyks (materials)
}

DOI: 10.31551/2410-2725-2018-4-2-321-339

\author{
Chernikov Sergei Sergeevich (1909-1976) \\ Candidate of History, Chief researcher of IIMK AN SSSR.
}

\begin{abstract}
The article of one of the leading Soviet archeologists S.S. Chernikov is reprinting of materials of scientific research about the Oyrat monuments of East Kazakhstan published in 1960 in notes of the Kalmyk research institute, language, literature and history (Chernikov 1960). The main objective of the repeated publication of the in our journal is the simplification of access to the publication of scientific community as, despite quite solid "age" of article, it is not losing the academic value to this day, and in the pithiness considerably surpasses some modern researches of Oyrat monuments of East Kazakhstan. Article is reprinted without corrections and adjustments by the current rules of grammar, a punctuation and spelling of Russian, only, according to requirements of the journal, references, the font and other components have been adapted.
\end{abstract}

Key words: monuments of Oyrat-Kalmyk; East Kazakhstan; written and archaeological sources.

\section{Ойрат-қалмақ архитектурасының ескерткіштері (материалдар)}

\section{Черников Сергей Сергеевич (1909-1976)}

тарих ғылымдарының кандидаты, КСРО ғылым академиясының Материалдық мәдениет тарихы институтының бас ғылыми қызметкері

Аңдатпа. Жетекші кеңес археологтарының бірі С.С. Черниковтың мақаласы 1960 жылы Қалмақ тіл, әдебиет және тарих ғылыми-зерттеу институтында (Черников, 1960 ж.) жарық көрген Шығыс Қазақстан бойынша ойрат ескерткіштері жайлы ғылыми зерттеулердің материалдары қайта басып шығарылды. Мақаланың қайта жариялануының басты мақсаты ғылыми қоғамдастықтың жариялануына қол жетімділікті жеңілдету, себебі мақаланың айтарлықтай үлкен «жасына» қарамастан, ол әлі де өзінің академиялық құндылығын жоғалтпайды және оның мазмұнында Шығыс Қазақстанның ойрат ескерткіштерінің кейбір зерттеу жұмыстарынан асып түседі. Мақала журналдың ережелері мен талаптарына сәйкестендіріліп, түзетулер енгізілместен, ағымдағы сілтемелер, шрифттер және басқа компоненттері ғана бейімделіп, грамматиканың, пунктуацияның және орыс тілінің жазуының түзетулерімен қайта басып шығарылды.

Кілт сөздер: ойрат-қалмақ ескерткіштері; Шығыс Қазақстан; жазба және археологиялық дереккөздер.

\section{Памятники архитектуры ойрат-калмыков (материалы)}

\section{Черников Сергей Сергеевич (1909-1976) \\ кандидат исторических наук, главный научный сотрудник ИИМК АН СССР.}

\footnotetext{
Аннотация. Статья одного из ведущих советских археологов С.С. Черникова является переизданием материалов научного исследования об ойратских памятниках Восточного Казахстана, опубликованных в 1960 году в записках Калмыцкого научно-исследовательского института, языка, литературы и истории (Черников 1960). Основной целью повторного издания статьи в нашем журнале является облегчение доступа к публикации научной общественности, так как, несмотря на довольно солидный «возраст» статьи, она до сей поры не теряет своей академической ценности, а по своей содержательности значительно превосходит некоторые современные исследования ойратских памятников Восточного Казахстана. Статья перепечатывается без исправлений и корректировок по текущим правилам грамматики, пунктуации и орфографии русского языка, лишь, согласно требованиям журнала, были адаптированы ссылки, шрифт и иные составляющие.

Ключевые слова: памятники ойрат-калмыков; Восточный Казахстан; письменные и археологические источники.
} 


\section{әОЖ/ УДК 904/908}

\section{Памятники архитектуры ойрат-калмыков (материалы) ${ }^{1}$}

\begin{tabular}{|c|}
\hline С.С. Черников \\
\hline (1909-1976)
\end{tabular}

1. Аблаинкит. Одной из наиболее неясных страниц истории народов СССР является история западной ветви монгольского народа, называвшегося ойратами, или калмыками, и создавшего во второй половине XVII в. обширное, но быстро исчезнувшее государство, в состав которого входила также и территория большей части нынешнего Восточного Казахстана. Если история ойратского государства оставляет еще много неясного, то еще меньше знаем мы о материальной культуре этого народа. Особенный интерес поэтому приобретают всякие крепостные и культовые сооружения ойратов. Остатки этих сооружений, находящиеся в Семипалатинской и Восточно-Казахстанской областях, Казахской $\mathrm{CCP}^{2}$, отмечались многими исследователями начиная с XVIII в., но до сих пор не подвергались специальному исследованию и раскопкам ${ }^{3}$. Известнейшим из этих памятников является укрепленный ламаистский храм Аблаинкит (монастырь Аблая), находящийся в 60 км к югу от Устькаменогорска, в Калбинских горах, у верховий правого притока Иртыша р.Себинки (Облакетки).

Появление ламаистских храмов на Иртыше в середине XVII в. (Аблаинкит основан в 1654 г.) объясняется политикой освоения недавно захваченных земель ойратскими фреодалами и установлением их контроля над намечающимися торговыми путями из России в Китай. Ойратское племя торгоутов появилось в верховьях Иртыша, Ишима и Тобола впервые в 1606 г. ${ }^{4}$ (Грум-Гржимайло 1926: 631).

Торгоуты (во главе с Хо-Урлюком) скоро ушли на Волгу, и их место заняло племя хошеутов, кочевья которых распространялись одновременно далеко на юг (до Нянь-Шаня), перемежаясь с кочевьями дербетов. В 1643 г. Гушихан ненадолго захватывает Тибет, что не могло не привести к сильному влиянию как ламаизма, так и тибетской культуры на хошеутовских ханов и тайшей. Именно в их среде появляется Зая-Пандита, первый проповедник ламаизма среди западных монголов. Зая-Пандита является приемным сыном Байбагус-хана, отца Аблая и Цэ-цэна. Влияние ламаизма, а также связи с Тибетом, именно в этой семье, должны были быть особенно сильными. Строитель Аблаинкита Аблай тайша имел владения на левобережье Иртыша, приблизительно от Устькаменогорска и р. Ур-Гурбан до р. Нарыма, включая сюда большую часть Калбинского хребта ${ }^{5}$. Ему принадлежали, вероятно, и низовья Бухтармы (Рыгдылон 1953: 77) ${ }^{6}$.

Помимо своих соплеменников хошеутов, кочевавших со своими стадами на этой территории, Аблай владел также и значительным количеством так называемых «пашенных бухарцев», переселенцев-пленников из земледельческих

\footnotetext{
1 Черников С.С. Памятники архитектуры ойрат-калмыков // Записки Калмыцкого научно-исследовательского института, языка, литературы и истории. - Элиста, 1960. - Вып. 1. - С. 115-134.

${ }^{2}$ Ныне, территория современной Восточно-Казахстанской области Республики Казахстан.

${ }^{3}$ Если не считать небольших разведочных раскопок Армстронга, Радлова и Влангели, о которых см. ниже.

${ }^{4}$ Донесение татарского воеводы Силы Гагарина.

${ }_{5}^{5}$ Судя по карте Семена Ремезова (Краткая сибирская летопись (Кунгурская), СПб, 1882) На этой карте показана р.Бешка, приток Иртыша, и на ней изображение полукруглой стены с надписью Булгагана. Южнее (но слишком близко) помещен г. Калмак Тологай, а на запад кочевья Аблая.

${ }^{6}$ На полустершейся монгольской надписи у входа в пещеру в низовьях р. Бухтармы читается имя Аблай. В этой же статье приводятся данные и о других монгольских надписях на территории Казахстана.
} 
районов Восточного Туркестана и Средней Азии, находившихся, возможно, в крепостной или полукрепостной зависимости от ойратских тайшей и зайсангов. «Пашенные бухарцы» жили оседло, в саманных домах, и доставляли кочевой знати необходимые земледельческие продукты. Захватив эту территорию, повидимому не ранее 30-х годов XVII в ${ }^{7}$, Аблай старался устроиться тут прочно, стремясь всеми мерами укрепить свое положение и обеспечить сохранность территории в бесконечных войнах ойратских фреодалов друг с другом. Этим и объясняются хорошие отношения Аблая с Московским государством. В середине XVII в. Россия стремительно продвигается на восток и захватывает Забайкалье и Чукотку. На Амуре в 1643 г. появляется Поярков, за ним в 1651 г. Хабаров. Впервые Россия сталкивается с Китаем. Одновременно укрепляется южная граница Западной Сибири и захватываются верховья Томи. В 1639 г. строится Ялотуровск, в 1663 г. - Тюкалинск и Царево-Городище (Курган), в 1670 г. - Ишим. На Томи вырастают в 1618 г. Кузнецк и в 1667 г. - Мунгатский острог. Московское правительство в этот период смотрит на Сибирь главным образом как на «земли собольные» и не видит еще проку и возможности для захвата степей, населенных к тому же воинственными кочевниками, часто нападавшими на русские пограничные укрепления (Шастина 1958) ${ }^{8}$. Рудные богатства Алтая и хозяйственное освоение степных пространств оказались по плечу только Петру I, когда экспедиции Бухгольца и Лихарева закончились постройкой Семипалатной и Устькаменогорской крепостей (в 1718 и 1720 гг.), обеспечивая тем самым прочное владение рудным Алтаем. В середине же XVII в. тобольский и тарский воеводы, ведя борьбу с последними Кучумовичами, естественно, должны были искать опоры среди степных фреодалов, враждебных сибирским татарам. Такими и были ойраты, в частности Аблай, сами в свою очередь заинтересованные в хороших отношениях с русским государством. В 1650 г. Аблай посылает в Тобольск послов с просьбой подарить ему панцирь Ермака, будто бы имеющий чудодейственную силу. Русское правительство, заинтересованное в дружественных отношениях с Аблаем, удовлетворило его просьбу и по приказу самого царя одарило его дорогими подарками, надеясь с помощью Аблая основательно укрепиться на тогдашних южных границах Сибири, чтобы обеспечить их от набегов «кучумовичей».

В 1654 г. Московское правительство посылает для переговоров с Китаем посольство во главе с боярским сыном Федором Исаковичем Байковым (Сахаров 1849: 126). Конечно, не случайно посольство едет в Пекин через владения Аблая тайши, передает ему «государево жалование» ${ }^{9}$ и зимует у аблаевых «пашенных бухарцев». Вероятно, поэтому пути ездил кто-то и до Байкова. Всего пробыл он у Аблая 7 месяцев и 7 дней, причем застал начало строительства Аблаинкита. Приведем выдержки из «статейного списка» посольства Байкова, касающееся Аблая ${ }^{10}$.

«А от пашенных бухарцев до Аблай тайши ходу день.

А в горах улусы калмыцкие, многие кочевья Аблая тайши.

А на той речке Бешке Аблай тайша делает город; а про то подлинно неведомо, каменной ли или деревянной; а лесу навожено много; лес сосновый тонок,

\footnotetext{
${ }^{7}$ Вероятно, что она была захвачена еще его отцом Байбагусханом.

${ }^{8}$ К нашему сожалению, эта работа освещает только события в Восточной Сибири, почти не касаясь Западной и отношений с ойратами. В книге приведена библиография вопроса.

9 Любопытно, что «государево жалование» было дано тогда только одному Аблаю.

${ }^{10}$ Выехав от Аблая, Байков благополучно добрался до Пекина, где и пытался начать переговоры. Дело сорвалось из-за того, что Байков отказался совершить земные поклоны перед богдыханом. После долгих пререканий он был отправлен обратно тем же путем и вернулся в Россию в 1658 г.
} 
как у нас на Руси в городех около огородов оплоты ставят; а ставят тот город промеж гор каменных, а мастеры ему присланы из китайского царства ${ }^{11}$. А на речке Бешке стоял Федор Исакович с Аблаем тайшею пять недель, пять дней».

Из этого описания явствует, что Аблаинкит был начат постройкой в 1654 г. и окончен, вероятно, через год или два. Аблай строил свою крепость на намечавшемся торговом пути из России в Китай, который шел от Тобольска через Ямышевские озера до Аблаинкита и дальше по северному берегу озера Зайсан, вдоль Черного Иртыша и южных отрогов Алтая, через южную Монголию в Китай. В этом и был основной смысл постройки крепости в столь, казалось бы, сейчас, глухом месте. После Байкова тем же путем прошло посольство тарского боярского сына Ивана Перфильева и многие торговые караваны (Путешествие через Сибирь 1882).

Связь Аблая с Россией крепнет. Панцирь Ермака и «государево жалование» успели принести кое-какие плоды. Из донесения некоего Ивана Ладыгина тарскому воеводе П.Г. Годунову в 1667-1668 гг. видно, что внук Кучума царевич Кучук совершал набеги на русские острожки и земли, пытаясь привлечь для этого ойратских тайшей и башкир. Ладыгин писал: что «стоит-де царевич вверх Ишиму за горой Юпаром во днище, а людей-де у него человек ста с четыре, худых и добрых, и прошал-де царевич у Калмыков людей идти войною на государеви городы и на слободы, и Калмыки ему людей не дали, и Абла-де тайша у него царевича аманатов взял в том, чтоб он не ходил безвестно на государевы городы и слободы воевать, а царевич до сего лета никуда войною небывал; и Абла-де тайша с башкирцев, которые приехали с царевичем, ясак взял, а имал ясак конми» (Дополнения к актам историческим 1853: 289).

Таким образом, Аблай без убытка для себя предотвратил один из очередных налетов на русскую пограничную линию. Но положение самого Аблая среди других ойратских фреодалов не было, по-видимому, достаточно прочным. Уже в 1660 г. Аблаинкит осаждает Цэцэн-хан, родной брат Аблая (Посольство к зюнгарскому хану 1892). С 1663 г. по 1665 г. между ханами ойратских племен идет ожесточенная борьба за первенство, в результате которой власть получает Сэнгэ из племен Дурбэн, сын Батыра хун-Тайчжи. Главный соперник его Цэцэн вовлек, вероятно, в эту борьбу и Аблая.

В 1671 г. Сэнгэ был убит Цэцэном и Цзотба батыром и претендентом на владычество над ойратами выступает знаменитый Галдан-Бошухту, единокровный брат Сэнгэ, в свою очередь начавший ожесточенную войну с Цэцэном. В том же году Галдан берет Аблаинкит и заставляет Аблая покинуть верховья Иртыша. Подробности осады нам неизвестны, во время штурма в Аблаинките сгорел, по-видимому, только верхний этаж дома, где жили ламы. Галдан сам, только что сложивший с себя в Тибете звание ламы, не тронул храма (пострадала только немного пристройка перед зданием). Храм с его библиотекой и крепостные стены остались стоять, обреченные на медленное разрушение.

Вытесненный с Иртыша Аблай, по-видимому, с частью подвластных ему хошеутов, откочевал на р.Урал, откуда часто нападал на торгоутов. В одно из таких нападений он был взят торгоутами в плен и выдан русским. Аблай умер глубоким стариком в Астрахани (Риттер 1860: 138). Торговый путь в Китай, так

\footnotetext{
${ }^{11}$ Мастера были скорее всего тибетские, но Байков не умел отличить китайца от тибетца.
} 
удачно проторенный при Аблае, впоследствии совершенно заглох (Путешествие через Сибирь 1882: 42) $)^{12}$.

В науке монастырь стал известен с 1720 г., когда после основания Устькаменогорска были пересланы Петру I тангутские и монгольские рукописи, доставленные из Аблаинкита, видимо, казаками, Петр I отправил их в Париж в академию для перевода и истолкования, где над ними работали бр. Фурмонт, приславшие Петру I (по незнанию тангутского языка) неправильный, выдуманный перевод. Разоблачил их Миллер, который прочел рукописи, оказавшиеся текстами религиозного содержания. Это были первые рукописи на этих языках, с которыми познакомились европейские ученые (Спасский 1818: 72; Риттер 1860: 190).

Первое описание самих зданий (видимо, записанное с чужих слов), мы находим у В. де Геннина (Генин 1837).

Краткие упоминания о Аблаинките и сделанных в нем находках рукописей обнаружены у Страленберга (Strahlenberg 1730) и Витсена (Vitsen 1785). Эти авторы уже связывают развалины с именем Аблая, видимо на основании известного им «статейного списка» Байкова. Витсен отмечает Аблаинкит на своей карте и дает историческую справку. «В той местности из скал вытекает речка Веска, при которой князь Аблай велел построить два каменных здания и укрепил их стенами, выбрав место между скал и отправив туда мастеров из Китая» ${ }^{13}$ (Радлов 1891).

Первое описание Аблаинкита, общий план и рисунок еще целого тогда храма, на основании собственных наблюдений было сделано в 1735 г. геодезистом Василием Шишковым, посланным в Калбинские горы для разведки полезных ископаемых ${ }^{14}$.

В июле 1734 г. Миллер и Гмелин, будучи в Усть-Каменогорске, посылали в Аблаинкит своих сотрудников и на основании их данных (а также и данных Шишкова) составили уже болёе подробное описание (Пекарский 1870: 323). Они же привезли в Академию наук большое количество рукописей и книг ${ }^{15}$. Описание Миллера (Радлов 1891), во многом дополняющее описание Аблаинкита Шишкова и наиболее полное: «...местность представляет красивую равнину, которую с С. и 3. (севера и запада - С.Ч.) замыкают высокие скалы. Скалы же, через которые проведены стены, местами сами заменяют стены, местами доставили камень для сооружения стен, местами окружают озеро, доставлявшее жителям воду; вследствие этого окружность местности похожа на пятиугольник. Самые стены вышиной в 11/2 сажени, толщиной $3 \frac{1}{2}$ локтя. Ворота южной стороны украшены колоннами из жженого кирпича, на которых, как и на воротах восточных, покоились своды из такого же кирпича, со временем обрушившиеся. Стены же повсюду сохранились. Входящим через южные ворота тотчас бросаются в глаза два здания, построенные на возвышении, которое в виде четырехугольника. С юга на возвышение ведет крыльцо. Взойдя на него, входишь в первое здание старинной постройки, которое, по моему мнению,

\footnotetext{
12 В отчете о посольстве (1675г.) Спафарий повторяет сведения об Аблаинките, явно заимствованные у Байкова.

${ }^{13}$ Цитирую по переводу В. Радлова

14 Описание это хранится в архиве Академии наук СССР, ф. 21, оп. 5, № 163 и опубликовано В. Радловым. См. Сбибирские древности 1891. Подлинные чертежи В. Шишкова хранятся в Свердловском областном архиве, Ф. 59, Оп. 3, Д. 1766. Точная копия с одного из них, публикуемая в настоящей работе, скопирована Е.А. Забелиным.

${ }^{15}$ Эти материалы хранятся сейчас в Институте востоковедения АН СССР, и содерж ат лишь религиозные тексты.
} 
служило сенями следующего затем второго здания. Кирпичные стены, покрытые составом из беловатой извести, возвышаются на $1 \frac{1}{2}$ сажени. Пол выстлан кирпичом... В двух углах находятся две крошечные круглые плавильные печи, сверху и снизу оканчивающиеся узенькими трубами, с отверстиями, в которые вставлялись меха; за исключением верхних частей, служивших для выхода дыма, они хорошо сохранились. Кроме указанного в той комнате ничего нет ни окон, ни крыши. Если же местами и проглядывают кое-какие следы крыши, то они казались как бы перегоревшими.

Второе здание, которое построено на том же возвышении, также состоит из одной комнаты, четырехугольной и более щегольской, переполненной идолами, рисунками и священными письменами. Это было само святилище... Вход в него со стороны первого здания или сеней; он прикрыт створчатой дверью, и так устроен, что, открыв дверь, свободно можно видеть святилище. По каждую сторону створок наши насчитали по 6 окон. Стены вышиной в 5 локтей, состоят из жженого кирпича, а потом на сажень из деревянных брусьев, которые постепенно соединяются в крышу. Посередине стоит четырехугольный пьедестал, вышиной в $3 \frac{1}{2}$ локтя, расписанный разными цветными орнаментами; на нем некогда стоял идол, изображавший стоящего и растопырившего голые ноги человека, с обнаженной головой... Наши нашли его разбитым на множество мелких кусков, тогда как еще несколько лет тому назад он был цел. Повреждению идол подвергся или по невежеству, или по неуместному усердию солдат из соседней крепости, часто посещающих эту местность ради охоты. Из доставленных мною остатков я мог заключить, что внутренность идола состояла из древесных ветвей, которые сначала были обмазаны глиной, а потом, по придании ему должного наружного вида, он сверху был окрашен более чистою белой известью, без малейших, впрочем, следов живописи или окраски. Шестнадцать других идолов такого же вида и устройства, но меньших размеров находились на меньших подставках, но, к сожалению, уцелели только одни подставки, вышиной в два локтя. Стены от самой подошвы до крыши разукрашены разными изображениями, из которых фигуры на восточной и западной стенах отличаются как величиной, так и формой тела. Что касается двух фригур на восточной стене, то одна изображает мужчину, другая - женщину; на западной стене фигуры женские. Все они изображены прямостоячими. Мужские фригуры особенно обращают на себя внимание множеством голов и рук. Из двух фигур на западной стене: у одной 4 головы и 24 руки, у другой 2 головы и 8 рук. Первая, кроме того, правою ногою наступает на волоса другого человека, поверженного к ногам ея, и смотрит на двух других, припавших на колена, людей. У третьей мужской фигуры, изображенной с противоположной стороны, также 2 головы и 4 руки; двумя руками она обнимает находящуюся возле ея женщину, другая же голова и остальные две руки ея находятся в прямом положении. Наконец, на северной стене изображен целый ряд сидящих женщин, с подогнутыми к лону ногами; их груди, руки и подошвы ног обнажены; у одних цвет тела натуральный, у других пурпуровый, у некоторых грязноватый, у иных зеленоватый. Несмотря на различное положение рук, они вообще очень сходны между собою. Кроме того, и весь потолок был украшен такими узображениями женщин, нарисованными на четырехугольных планках в 1 локоть величиною; хотя большая часть их в то время уже была сорвана и унесена, но их, по словам наших людей, осталось еще несколько сот... Заслуживает внимания, что на большей части картин фригуры, особенно головы, ркружены световыми лучами или так 
называемым нимбом, которым, как известно, и Римляне окружали некогда свои божества, и у нас украшают изображения святых.

В той же комнате, у северной стены, стоял значительной величины шкаф, со многими выдвижными ящиками, в которых хранилось священное собрание тангутских и монгольских рукописей. С тех пор как нечестивые руки опрокинули его, оне (то есть рукописи) лежат разбросанными по всей комнате, и хотя в течение стольких лет при всяком случае сильно растаскивались русскими солдатами и охотниками, в наше же время в иртышских острогах употреблялись для завертывания товаров и заклейки окон, а наконец, и нашими были увезены в значительном количестве, все-таки, как говорят, осталось там столько, что их едва ли можно бы было увезти на 10 лошадях. Дошедшие до меня монгольские и калмыцкие листы большей частью писаны на простой белой бумаге черными, или (что встречается реже) вперемежку красными и черными, либо целиком красными буквами. Писанных по тангутскому способу на черной бумаге золотыми буквами я видел немного. Книги из березовой коры (таких я добыл оттуда три, писанные на калмыцком языке) хотя и не принадлежат к числу обычных, но и не могут считаться особенно редкими. Они указывают только на неимение бумаги; точно так нам известно, что в отдаленных местностях Сибири русские, за отсутствием бумаги, иногда употребляли березовую кору.

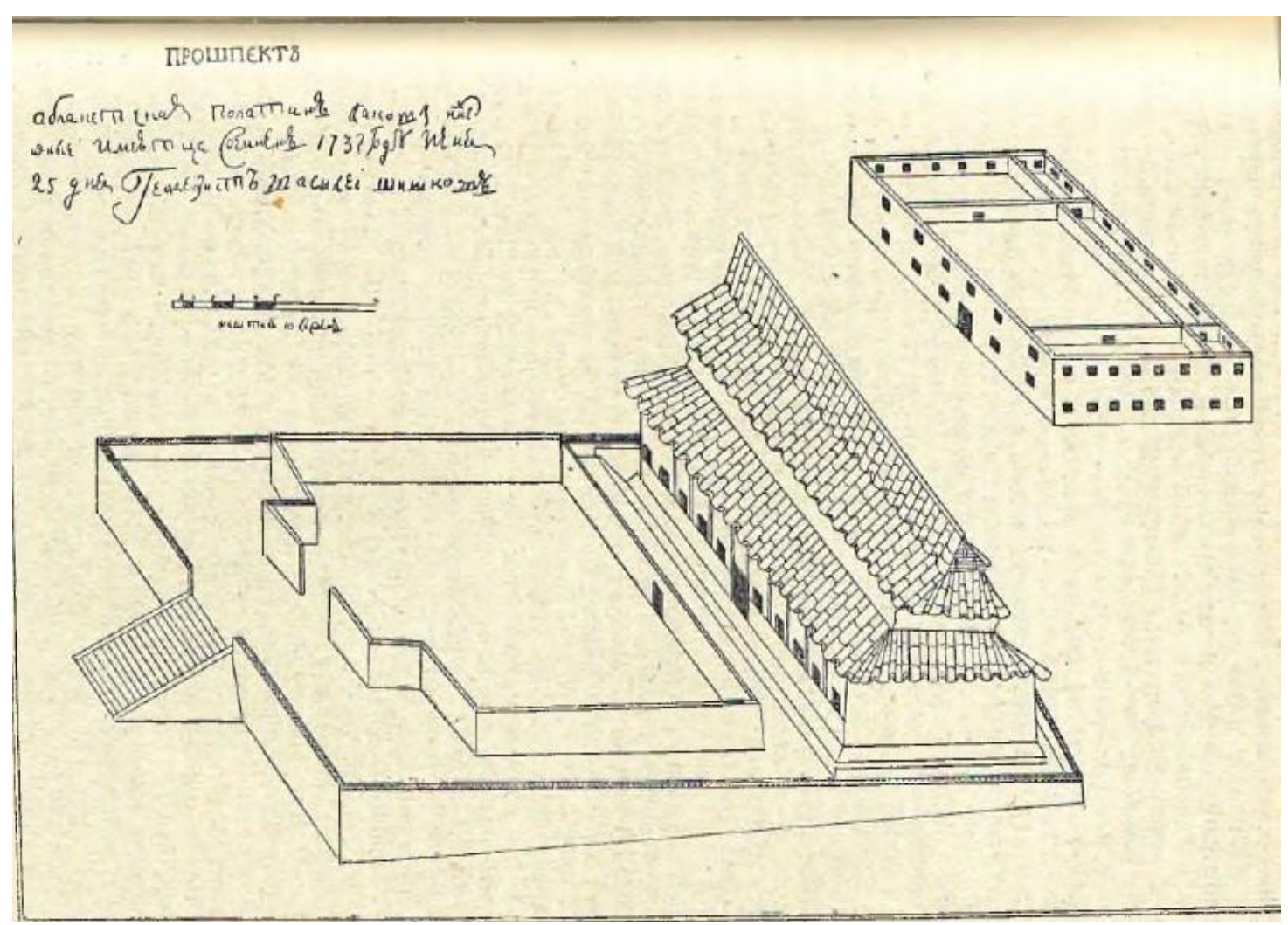

Рисунок 1. План Аблайкита, снятый в 1773 г. геодезистом Василием Шашковым (Свердловский областной государственный архив Ф.59, Оп.53, Д.1766/7)

Возле восточных стен ворот построено другое здание, в котором, кажется, жили жрецы. Оно состоит из одной большой комнаты и нескольких отдельных помещений по бокам... Стены здесь, как и в прочих зданиях, кирпичные, без 
всяких украшений живописных, покрыты беловатым глинистым составом. Вот все, что от него уцелело. Говорят, что сделанные из китайского шелка ковры, которыми они были украшены в этом и предыдущем здании, сильно пострадав уже от времени, увезены первыми находчиками. Следует, впрочем, заметить, что эти три, рписанные нами, здания так построены, что дверями обращены на юг. Такого расположения дверей калмыки и монголы, по унаследованному от предков обычаю, строго придерживаются при постройке не только священных, но и остальных своих зданий, как об этом свидетельствует Рубруквис.

Наконец уцелели еще развалины какого-то меньшего здания на запад от двух первых. Стены его едва выше полуроста человеческого; посередине видны следы очага...»

Таким образом, на пространстве, обнесенном стеной, было всего три здания. На высоком искусственном фундаменте с кирпичными перилами стоял главный храм с пристройкой перед ним. Верх стены и крыша этой пристройки, видимо, были деревянные, сгоревшие при взятии крепости. Окна находились в деревянной части стены. Сам храм построен из белого кирпича, имел деревянный верх и крышу из черепицы, покрытую зеленой и голубой глазурью. Пол в храме кирпичный. Второе здание кирпичное, с деревянным вторым этажом, также уничтоженное пожаром, судя по планировке, было жилым. Мнение Миллера о том, что это был дом лам, вероятно, соответствует действительности. Наконец, на запад от храма находилось невысокое сооружение, явно хозяйственного назначения, какого именно - неизвестно. Вся свита Аблая, а также и он сам, предпочитали войлочную юрту (вполне основательное предположение Палласа).

После Миллера и Гмелина (Gmelin 1793) (последний не дал нового материала) Аблаинкит посещали и другие исследователи, отмечавшие все большее и большее разрушение памятника.

Летом 1770 г. в Устькаменогорске был Паллас (Паллас 1786: 258). Из описания Палласа (для обследования Аблаинкита он посылал своего сотрудника студента Соколова) можно заключить, что памятник продолжал быстро разрушаться. В Аблаинките размещался тогда эскадрон кавалерии.

Сиверс (Sievers 1796: 219), проезжая в 1791 г. с ботанической экспедицией через Калбинский хребет, остановился на завтрак у казахского мавзолея, выстроенного из белого аблаинкитского кирпича.

В 1811 г. Аблаинкит посетил Г. Спасский. К этому времени от зданий остались только стены, которые растаскивались на кирпич. Все деревянные части зданий, живопись, постаменты для статуй богов, все сгнило или было уже унесено. Приведя довольно подробное описание памятника, Спасский опубликовал и рисунок развалин, видимо снятый с натуры. Видно, что стены храма и ворота были еще целы.

Ледебур, побывавший в Аблаинките в 1826 г., дает краткое описание уцелевших стен и фундамента главного здания и прилагает рисунок обломка растительного орнамента стены из обожженной глины. Он сообщил также, что некоторые казахские могилы были сделаны из кирпича Аблаинкита.

Чихачев (Tchichatcheff 1845) отмечает, что в 1843 г. продолжалось дальнейшее растаскивание кирпичей уже на постройку Устькаменогорска. Купец Забнин говорил ему, что он целыми возами отправляет материал Аблаинкита в Устькаменогорск. Из этого же материала были построены многие казахские могилы и почтовые пикеты (Себинский и Сенташский). На приложенном в его книге рисунке видна уже только стена с сохранившейся аркой над восточными воротами. 
Влангели (Влангели 1853) в 1851 г. произвел детальное обследование Аблаинкита, даже с небольшой разведочной раскопкой фундамента главного возвышения. В обстоятельном описании памятника он дает подробные сведения о состоянии стен и остатков зданий. Пробная раскопка - «яма несколько больше аршина» - показала, что материал фундамента состоит из тонких перемежающихся слоев глины и земли, на которых и была возведена постройка. От зданий остались только обломки кирпича и облицовки с орнаментом, остатки печей (обожженные кирпичи) и гранитные пьедесталы колонн в виде квадратных плит со стороной в 18 вершков и высотой до 13/4 вершка. В углу главного возвышения Влангели нашел обрывки бересты с монгольскими или тибетскими письменами.

Радлов ${ }^{16}$ обследовал Аблаинкит в 1865 г. и произвел также пробную раскопку на главном возвышении. На возвышении кое-где видны были еще следы стен в виде «лежащих в порядке гранитных плит, довольно тщательно обсеченных».

Никитин (Никитин 1902: 107), посетивший Аблаинкит в 1900-1901 гг., дает краткое описание его и приводит рассказы местных жителей о каких-то раскопках на главном возвышении.

Андрианов (Андрианов 1929: 10) посвятил описанию Аблаинкита большую часть своей статьи и, видимо, большую часть времени в поездке 1928 г. Работа его содержит поверхностный исторический очерк Аблаинкита и описание современного состояния памятника. К статье приложена карта с маршрутом поездки и очень неточный план Аблаинкита.

Помимо перечисленного, упоминания о Аблаинките есть почти у всех авторов XVIII и XIX вB., так или иначе касавшихся географии и истории Верхнего Прииртышья ${ }^{17}$. Можно смело сказать, что никакой другой памятник Казахстана не пользовался такой широкой известностью в научных кругах. Однако до сих пор все изучение его сводилось к наружному описанию (более или менее точному и подробному). Аблаинкит является одним из немногих памятников, на котором мы можем проследить все стадии его последовательного разрушения, отмечаемые различными исследователями в течение более чем 200 лет.

Перейдем теперь к описанию состояния Аблаинкита по материалам наших обследований 1935 и 1937 гг. (также поневоле ограничившихся лишь наружным описанием).

Местность для крепости выбрана очень удачно. Это - отрог гранитных тор, со всех сторон окруженный долинами (в 2-3 км шириной) pр. Талды и Талды-Булак (Рисунок 2). Таким образом, крепость господствует над долиной р.Облакетки, Сеи бинскими озерами и закрывает путь с Запада в долину Таргына и далее к Иртышу.

Рядом с крепостью находятся также лучшие во всем районе пастбища. Храм и жилые строения были расположены у подножия отрога и обнесены стеной, которая тянется вокруг всего отрога по вершинам гор (Рисунок 3). Главное возвышение, на котором стоял храм, представляет собой правильный четырехугольник, ориентированный с севера на юг, размером 75x37 м. Южная сторона находится прямо против вороти менее крута, чем остальные. По расположению осыпавшихся камней можно угадать, что здесь была лестница. Почти по всей длине восточной стороны сохранилась кладка из плит сланца, связанных глиняным раствором. Ближайшие выходы сланцев находятся на южном конце долины р.Талды-Булака, километрах в 2 от крепости. Западная сторона более сглажена; кладка почти не видна. Поверхность возвышения со-

\footnotetext{
${ }^{16}$ Отчет археологической комиссии за 1866 г. стр. XXIV; см. также архив ИИМК, дело №8, ИАК

${ }^{17}$ Например: Левшин, Гумбольдт, А. Ремюза, Гуляев, Кастанье, Семенов-Тяньшанский и др.
} 
стоит из серой земли с большим количеством обломков кирпича, в изломе серого цвета, с большим количеством гальки, но водоупорного и звенящего при ударе; попадается и красный кирпич. Встречаются также обломки глиняных полукруглых в сечении черепиц и обломки глиняной облицовки, иногда с растительным орнаментом, в виде расположенных фестонами валиков. Часть из них покрыта яркой голубой, зеленой и реже красной глазурью. В юго-восточном углу возвышения следы раскопок в виде большой (диаметром около 3 м) ямы и отвала вынутой земли. Небольшие ямы есть и в других местах возвышения. На сороковом метре от южной стороны проходит неглубокая канава, севернее ее вся площадь насыпи повышается приблизительно на 30 см. Судя по описаниям, здесь было здание храма. В юго-восточной части его обнаружены сланцевые кладки. По-видимому, это не только насыпь, но и остатки Фундамента самого- здания. Глазурованных обломков в северной части возвышения; нет. Встречаются только кирпичи и черепица из серой глины. Приблизительно в 30 м на северо-запад от главного возвышения находятся 2 большие ямы: перед нами - полукруглый ров и вал. На валу лежат большие глыбы гранита. В передней яме лежат такие же глыбы, носящие следы огня. «Жилище лам и знатных особ» представляет собой сильно заплывшее возвышение, неправильной четырехугольной формы, размером 29х28 м, все покрытое ямами. Возвышение состоит из земли, обломков серого и красного кирпича. На остальном пространстве внутри стен никаких следов построек нет.

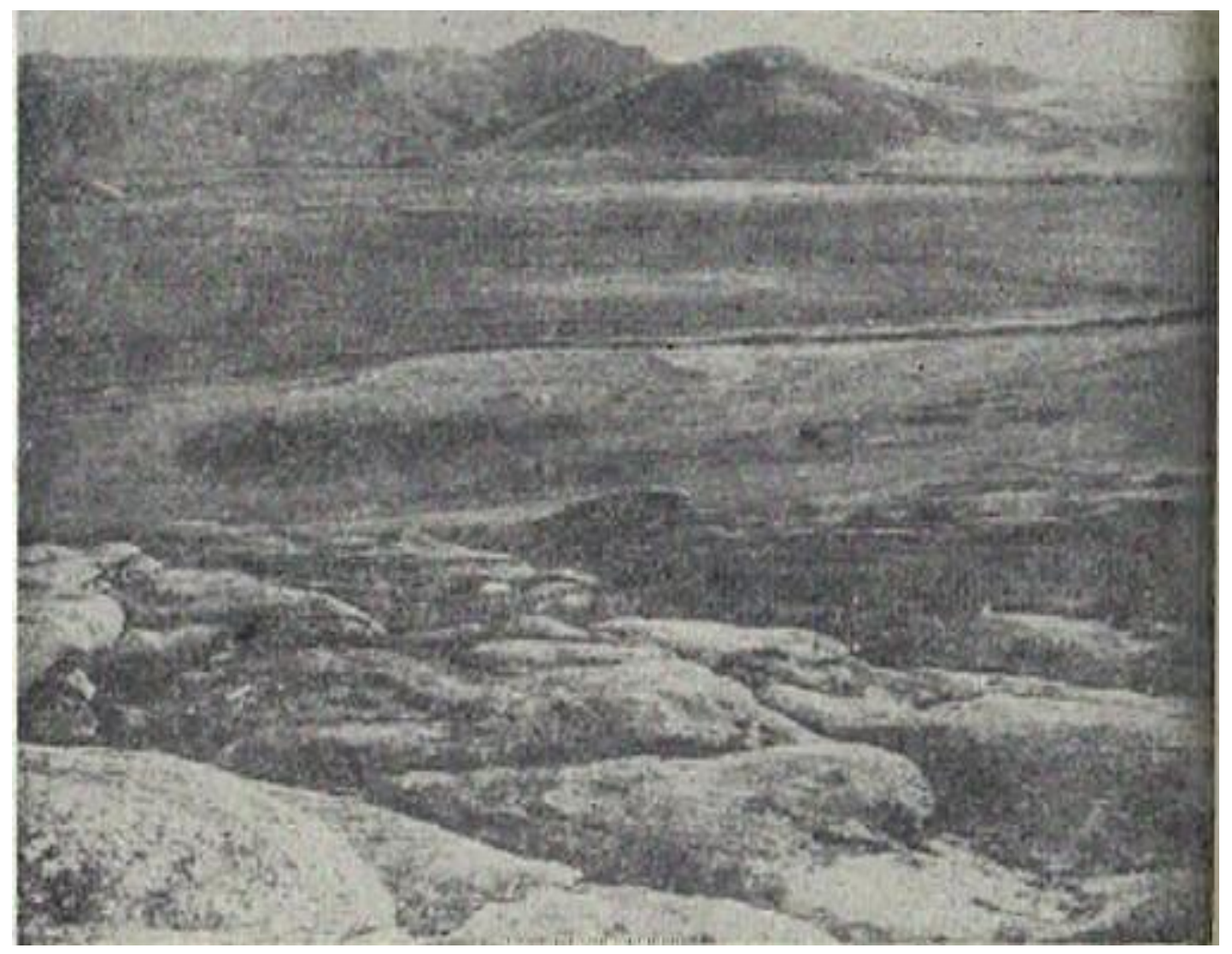

Рисунок 2. Вид Абланкита с северного отрога (1937) 


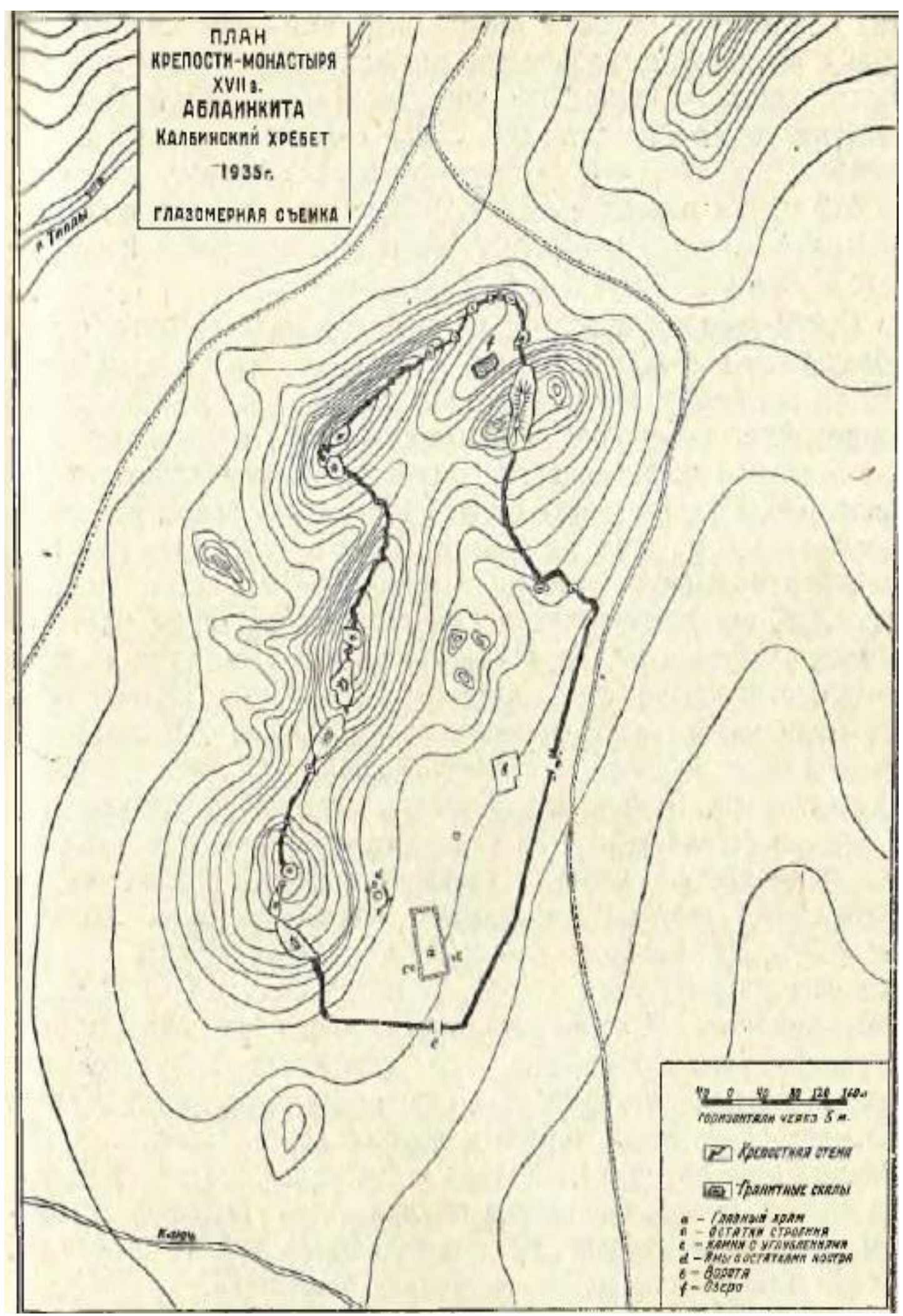

Рисунок 3. План Аблаинкита (1935) 
Стены крепости сложены из плит сланца и гранита, с преобладанием последнего. В южной части, то есть в низине, стена сильно разрушена и заплыла; там, где она идет по гранитному отрогу (северо-западная и северная стены), сохранилась лучше. В южной части видно, что камни связаны глиняным(?) раствором. При постройке стены были использованы естественные преграды в виде скал гранита. Во многих местах стена прерывается большими глыбами и затем продолжается дальше. Северная, северо-западная и северо-восточная стены идут по самому гребню горы. На поворотах и между скалами (в северозападной части) стена выступает полукругом. Несомненно, это были наиболее укрепленные места крепости. В северо-восточной части крепости в гранитной скале есть глубокая ниша, вроде пещеры. В этой пещере видны следы долговременных костров и стенки ее слегка зашлифованы. Это место производит впечатление наблюдательного пункта. Сохранившаяся часть стены достигает 2 м высоты. Всего стена была высотой около 3 м. Это видно по следам ее на глыбах гранита, где рядом идет двухметровая кладка. Толщина стены 1-1,20 м. В восточной и южной части есть остатки трех ворот. У восточных, шириной 4,5 м, сохранились три гранитных прямоугольных столба. В южной части было, повидимому, двое ворот. В стене два прохода на расстоянии 5 м друг от друга. Ширина обоих южных ворот около 5 м. Метрах в ста от южных ворот крепости находится кольцеобразная выкладка из больших обломком гранита, несомненно, значительно более раннего происхождения ${ }^{18}$. Таково современное состояние памятника.

Аблаинкит был наиболее известной, но далеко не единственной постройкой ойратов в казахстанских степях. Большинство нз этих построек или исчезли совсем, или представляют собой развалины, еще более незаметные, чем Аблаинкит. Ни по одному из этих сооружений нельзя точно проследить его историю, а у некоторых нельзя даже установить имя строителя и год постройки.

2. Семь Палат. Это те самые здания, ныне совершенно исчезнувшие, которые дали свое название г. Семипалатинску. По всей вероятности, их постройка была одной из первых попыток калмыков создать оседлые поселения на Иртыше. Г.Ф. Миллер в своем донесении Сенату и Академии наук 20 мая 1735 г. пишет о найденной им в Тюмени грамоте Михаила Федоровича от 25 октября 1616 г., где эти постройки называются «Каменными мечетями». Следовательно, в 1616 г. они были уже построены. Строительство это Миллер связывает с именем ламы Дархан-Дорджи и называет монастырем. Повидимому, Семь Палат были построены торгоутами до переселения их на Волгу. Первое краткое описание Семи Палат дает В. де Геннин, затем В. Шишков. Наиболее подробное описание памятника мы находим у Миллера: «Лежат оне на возвышенной и безлюдной, по природе своей степи, неподалеку от берега реки Иртыша. Самое название показывает, что всех зданий 7. Большая часть их построена из сырцового кирпича. Только одно строение, бывшее, кажется, главным, на полвысоты состоит из плитняка, вырытого, по-видимому, в той же местности. Здания имеют все четырехугольную, некоторые продолговатую фрорму. Величина зданий различна, но ни одно из них не превышат 15 обыкновенных шагов; стены редко толще 2 футов. Одно здание по четырем углам поддерживается колоннами из того же сырцового кирпича. Одно возвышается наподобие пирамиды, постепенно суживаясь. Одно разделено на 3 комнаты. Одно, отстоящее на $1 / 2$ версты, меньше остальных, но выше их, почему и называется башней, построенной для караульных. Они уже почти все обрушились

\footnotetext{
18 Подобные сооружения описаны А.А. Андриановым (Андрианов 1916). Судя по находкам, сделанным при раскопках одного из таких колец, они относятся ко времени ранних кочевников VII-V вв. до н.э.
} 
или грозят скорым разрушением. Нужно удивляться, как они при таком способе постройки еще простояли столько времени, то есть более столетия. Крыши, если только можно положиться на некоторые остатки их, по-видимому, состояли из древесных сучьев. Внутри, местами, по стенам видны остатки живописи, которые изображают людей, частью стоящих, частью сидящих, животных, драконов, птиц и преимущественно цветы, с переплетающимися между собою стебельками и листьями. В трех зданиях лежит большое количество свалившихся деревянных колонн, местами разукрашенных цветами, резных деревянных изображений животных (львов и драконов), сидящих на колоннах, которыми, по-видимому, подпирали верхние стропила (или потолки). Одну из таких фригур я отправил в Императорскую кунсткамеру... По словам Витзена, «от этих зданий (то есть от Семи Палат - С.Ч.) вверх по Иртышу живет калмыцкий жрец, который построил себе два довольно больших кирпичных здания, снаружи покрытых известью; он содержит при себе Бухарцев и живет землепашеством: там растут пшеница, ячмень, горох и другие злаки. Бухарцы, состоящие при нем, покинули свою собственную родину и поселились на этом месте» (Риттер 1860: 139-142).

Семь Палат, разрушающиеся со временем все больше и больше, описывают Паллас (Паллас 1786: 191), академик Фальк (Фальк 1824: 221) и Христофор Барданес, однако их описания ничего нового не дают. Примерно к началу XIX в. Семь Палат разрушились окончательно. В 1857 г. при нивелировке берега Иртыша Армстронг (Армстронг 1861) произвел на этом месте небольшие раскопки и обнаружил арки с коробчатым сводом из необожженного кирпича, положенного на глине плашмя в 2 ряда. Длина арки - 2 аршина. Высота $-1,5$ аршина. Арки доверху были заполнены песком. Видимо, это был фундамент или подвал одного из зданий. Найдены были бычий и человеческий черепа с нарисованными на них зеленой, желтой и красной краской знаками ламаистского культа, шиферная пластинка с грубым изображением субургана (?), глиняный сосуд и другие вещи, которые ныне хранятся в отделе Востока Государственного Эрмитажа в Ленинграде.

После Армстронга описание остатков Семи Палат никем не производилось.

3. Бошухту-хан-Кит. На р. Кальджир при впадении в нее речки Орды нами были обследованы остатки большой крепости с саманными стенами и с развалинами саманного же здания в центре (Рисунок 4). Крепость расположена на равнине, вплотную примыкая к левому - обрывистому берегу Кальджира. Внешние стены, сильно расплывшиеся, были сложены из сырцового кирпича. Восточная стена длиной 600 м и высотой от 1,5 до 5,5 м. Стена прерывается в трех местах. Сквозь эти проемы входит внутрь крепости небольшой ручеек и современная дорога.

В 40 м к западу от стены находится круглый холм высотой 2,5 м с ямой в центре. Южная стена длиной 420 м и высотой 3,40-2,40 м прерывается в месте, где проходит тракт на с. Буран. Западной стороной крепость упирается в обрывистый берег Кальджира. В 60 м от западного конца северная стена имеет с внутренней стороны выступ шириной в 15 и длиной в 18 м. В тот же проем, где проходит тракт, изнутри крепости выходит арык, пересекающий ее с севера-запада на юго-восток, видимо позднейшего происхождения. Северная стена длиной 480 м, высотой 1,20-0,80 м и прерывается в месте, где проходит тракт (в западном конце). В 20 м от стены в западной ее части находится холм с остатками строений (видимо, современных). Восточной стены вдоль берега Кальджира нет. Проемы в стенах, образованные дорогой, видимо, сделаны во время ее прокладки. В юго-восточной части прямоугольника, образованного 


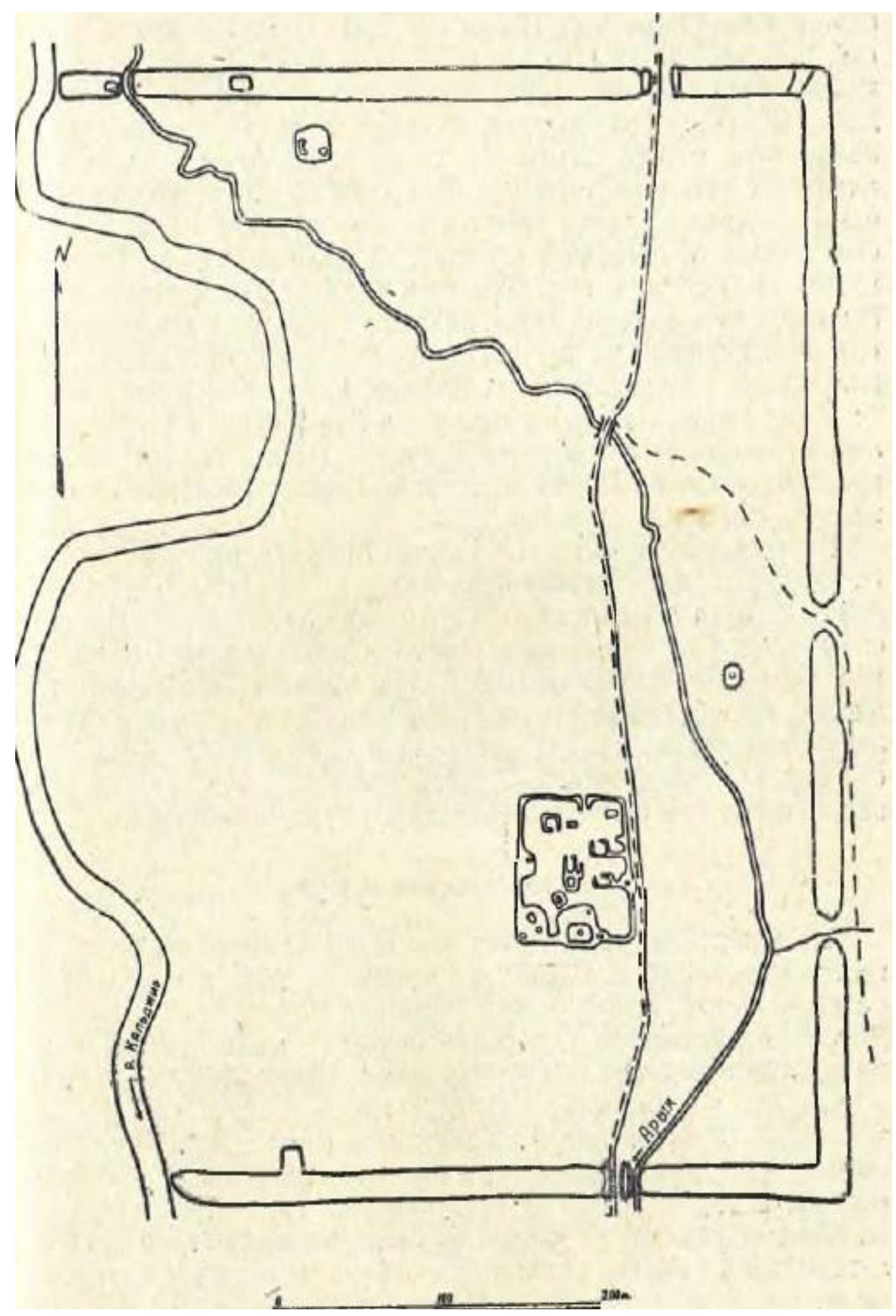

Рисунок 4. План Бошухту-хан-Кита (1937) 
внешними стенами, находится внутреннее укрепление, имеющее в плане неправильную квадратную форму. Стены его также сложены из сырцового кирпича с примесью гальки. Длина стен 75-80 м, высота 4,8-6,3 м. В северной части имеются ворота шириной 6,5 м. Внутри стен находятся остатки 5 строений из того же сырца. В центре восточной, южной и западной стен находятся выступы внутрь. На восточном выступе были найдены обломки обожженного красного кирпича, на южном - обломки глиняного сосуда серого цвета, сделанного на гончарном круге. Такой же выступ (с двумя ямами на нем) имеется и в югозападном углу укрепления. Вплотную под восточной стеной (частично срезав ее) проходит тракт на Буран. У ворот находятся развалины современного саманного строения.

По сообщению Риттера (Риттер 1860: 141), Галдан-Бошухту построил в 70-х годах XVII в. ламаистский храм недалеко от озера Зайсан-Нор, в 6 днях пути к юго-востоку от Аблаинкита. Паллас (Pallas 1801: 132) отмечает его как один из самых оживленных и многолюдных монастырей. Он был разрушен в 1689 г. На примере Аблаинкита мы видели, что буддийский храм у ойрат иногда сочетался с укреплениями. Никаких других развалин в окрестностях озера Зайсан-Нор нет, следовательно, обследованные нами остатки крепости, вероятнее всего, и являются Бошухту-хан-Китом.

4. Калбасунская башня. Эта постройка, являвшаяся чем-то вроде часовни, была известна еще в 1898 г. Семену Ремезову, который и поместил ее на своей карте. Материалами Ремезова пользовался также и Витсен. Единственное подробное описание Калбасунской башни приводит Миллер: «Проезжая летом 1734 г. по этим местам, я услышал в ямышевском остроге много интересного про эту так называемую башню. Говорили, что (она) имела совершенно четырехугольную форму, что все стены ее были одинакового объема, а покрывавший ее свод снаружи состоял из 20 углов, из которых уцелело 12. Стены до свода были вышиной приблизительно в 4 сажени, толщиной в 3 фута. С наружной стороны их видны концы деревянных балок, вставкою которых, без сом нения, хотели укрепить стены.

Стены внутри, судя по некоторым остаткам, были выбелены каким-то составом. Сверху, около свода, видны два окна с 2 противоположных сторон. Справа, около подошвы, находится еще одно окно. Кроме того, на самой верхней части свода видно отверстие, по-видимому также служившее окном. Дверь бы ша с той стороны, которая обрушилась. Вся постройка состоит из жженого ярко-красного кирпича. На географической карте Витсена она значится, но помещена слишком далеко от Иртыша и упоминается таким образом: «Калбасим, или Кабалганкум, - каменное, но уже обрушившееся здание» (Радлов 1891: 57).

По сведениям Риттера (Риттер 1860: 138), постройка эта называлась Джалин-Обо, по имени тайши Джалина, бывшего в этих местах в 1680-1702 гг., когда под натиском казахов он откочевал на Восток ${ }^{19}$. Джалин-Обо окончательно исчез с лица земли еще в XVIII в., как и Аблаинкит, скорее всего растасканный на кирпичи.

\footnotetext{
${ }^{19}$ Дата оставления Джалин-Обо указана здесь неточно. Вероятно, он был покинут в 90-х годах XVII в, так как на карте Ремезова он отмечен.
} 
5. Кентский дверец. В районе Каркалинска в Кентских горах находятся развалины еще одного каменного здания, напоминающего Джалин-Обо. Подробное описание его дает В. Никитин (Никитин 1896). В несколько сокращенном виде оно приводится ниже: «Вблизи ключа Кызыл-Кенч, в урочище того же названия, имеются развалины какого-то здания, по народной молве Кентского дворца. Здание это небольшое: в длину и ширину не превышает 5 сажен; с трех сторон - с северной, восточной и западной - к зданию примыкают небольшие прямоугольные пристройки, неодинаковой величины.

Об этой же постройке существует такая легенда. Во время борьбы калмыков с киргизами калмык Айд-батыр полюбил дочь (Лауке) Косан-Серен-хана, но так как Косан-Серен-хан добровольно свою дочь не отдавал за Айд-батыра, то последний украл ее, а с нею увел 40 девушек и 40 нокеров (слуг). Долго они странствовали в степи, но там было небезопасно, киргизы уже завладели степями и ежеминутно могли напасть на беглецов. Тогда они ушли в Кентские горы, где и застала их зима; чтобы укрыться от холода и буранов, Айд-батыр построил себе дворец к зажил в нем, не заботясь о будущем. Так прожил Айдбатыр в этом укромном месте некоторое время покойно и счастливо. Но когда калмыкам в борьбе с киргизами пришлось очень плохо, брат Айд-батыра Тлеуке-батыр, спасаясь от киргизов укрылся также в Кентских горах, где и повстречал своего брата, и стал звать его с собою идти на врагов. Однако ни увещания Тлеуке оставить Лауке, ни укоры за то, что брат наслаждается, когда все сородичи борются за свою жизнь и свободу, ни проклятья - ничего не подействовало на Айд батыра. Он лично был счастлив, а ко всему остальному был равнодушен. Он говорил: «Борьба теперь напрасна, дело проиграно, и рано или поздно смерть все равно меня не минует; так пусть же она сама придет ко мне чем сам я пойду к ней, а пока еще ея нет и пока она далеко, пусть счастье улыбается до последней минуты...» И последняя минута пришла скорее, чем сн ждал ее. Тлеуке возненавидел брата и, сговорившись с нокерами, убил Айд-батыра, Лауке и всех девушек, а сам со своими воинами и нокерами брата отправился на войну, но был побежден и убит. То был последний калмык, как говорит легенда» (Никитин 1896).

Вероятно, Кентский дворец является Учурту-хан-Китом, о котором Риттер (Риттер 1860: 141), по материалам Миллера, сообщает следующие сведения. Старший брат Аблая и тесть Галдана-Бошухту Учурту тайша сделался самостоятельным владетелем в 1672 г. (то есть после ухода Аблая с Иртыша, дата здесь, видимо, не точна). Он построил храм в 5 днях пути к западу от зладений Аблая. Храм вскоре был разрушен Галданом, а Учурту тайша был изгнан им с занимаемой территории. От Кентских гор до Аблаинкита немного больше 400 км, следовательно, на хорошем коне, без груза, этот путь в 5 дней проделать можно. Никаких других развалин к западу от Аблаинкита никем не отмечено.

6. Ойратские монастыри на р. Или. Долина р.Или была политическим центром ойратских кочевий, и там, вероятно, было много памятников их зодчества. В войнах с Китаем середины XVIII в. все они были уничтожены. Перечислим их: это монастыри Цаган-Сумэ, у речки Дерга-ланг, близ р.Или и Майдара, на р.Кайнух, близ левого берега р.Или. Кумирня в 6 верстах от Каргоса на р.Аминту (Фальк 1824: 49). 
Итак, ойрат-калмыки, известные нам главным образом по письменным историческим источникам, имели довольно высокую материальную культуру, в частности различные архитектурные, крепостные и культовые сооружения.

\section{Әдебиеттер тізімі/ Список литературы}

1. Андрианов А.В. К археологии Западного Алтая // Известия императорской археологической комиссии. - 1916. - Вып. 62.

2. Андрианов А.В. Материалы по археологии Устькаменогорского района // Труды Семипалатинского окружного музея. - 1929. - Вып. 2.

3. Армстронг И.А. Семипалатинские древности. // Известия археологического общества. - Т. II. СПб, 1861.

4. Влангели. Географрические поездки в восточную часть Киргизской степи. - Т. І. - СПб, 1853.

5. Геннин В. де. Описание уральских и сибирских заводов. - М.,1837.

6. Грум-Гржимайло Г.Е. Западная Монголия и Урянхайский край. - Ленинград, 1926.

7. Дополнения к актам историческим, собранные и изданные археографической комиссией. СПб, 1853. - Т. V.

8. Записки путешествия академика Фалька. Полное собрание ученых, путешествий по России. T. IV. - СПб, 1824,

9. Никитин В. Памятники древности Каркаралинского уезда // Записки Русского археологического общества. - Т. VIII. - Вып. І. - Т.2. - СПб, 1906.

10. Паллас П.С. Путешествие по разным местам Российского государства. - Ч. II. - Кн. 2. - СПб, 1786.

11. Пекарский П.П. История Академии наук. - Т. І. - СПб, 1870.

12. Посольство к зюнгарскому хану Хун Тайчжи Цэван-Рабтану капитана от артиллерии Ивана Унковского (1722-1724) // Записки Императорского Русского географического общества по отделению этнографии. - СПб, 1892. - Т. Х. - Вып. ІІ.

13. Путешествие через Сибирь от Тобольска до Нерчинска и границ Китая русского посланника

Н. Спафария в 1675 г // Записки Императорского Русского географического общества по отделению этнографии. - СПб, 1882. - Т. Х. - Вып. І.

14. Радлов В. Сибирские древности. - СПб, 1891. - Т. І. - Вып. 3.

15. Ремезов С. Краткая сибирская летопись (Кунгурская). - СПб, 1882.

16. Риттер К. Землеведение Азии. - Т. ІІІ. - СПб, 1860.

17. Рыгдылон Э.Р. Остатки монгольской надписи у Бухтарминской пещеры // Эпиграфика Востока. - 1952. - Вып. 7. - С. 77-80.

18. Сахаров Н. Сказания русского народа. - Т. ІІ. - СПб, 1849.

19. Спасский Г.И. Древности Сибири // Сибирский вестник. - СПб., - 1818. - Ч. III.

20. Черников С.С. Памятники архитектуры ойрат-калмыков // Записки Калмыцкого научноисследовательского института, языка, литературы и истории. - Элиста, 1960. - Вып. 1. - С. 115-134.

21. Шастина Н.П. Русско-монгольские посольские отношения XVII века. - М., 1958.

22. Gmellin I.G. Reise durch Siberien. - СПб, 1793.

23. Pallas P.S. Sammlungen histouschen Nachrichten uber Mongolischen Volkershaften. - T.11. - СПб, 1801.

24. Sievers B. Sibirische Briefe. - СПб, 1796.

25. Strahlenberg F.I. Das Nord - und ostliche Theil von Europa und Asia. - Stokholm, 1730.

26. Tchichatcheff P.A. Voyage dans l'Altaj. - Paris, 1845.

27. Vitsen N. Noord en Oost Tarfarie. - Amsterdam, 1785.

\section{Reference}

Andrianov 1916 - Andrianov, AV 1916, The archaeology of West Altai, Izvestija imperatorskoj arheologicheskoj komissii, Vyp. 62. (Andrianov, AV 1916, K arheologii Zapadnogo Altaja, Bulletin of the Imperial archaeological Commission, Issue 62). (in Rus).

Andrianov 1929 - Andrianov, AV 1929, Materialy po arheologii Ust'kamenogorskogo rajona, Trudy Semipalatinskogo okruzhnogo muzeja, Vyp. 2. (Andrianov, AV 1929, The materials on the archeology of the UstKamenogorsk district, Proceedings of the Semipalatinsk district Museum, Issue 2). (in Rus). 
Armstrong 1861 - Armstrong, IA 1861, Semipalatinskie drevnosti, Izvestija arheologicheskogo obshhestva, T. II, Saint Petersburg. (Armstrong, IA 1861, Semipalatinskie drevnosti, Izvestija arheologicheskogo obshhestva, T. II, Saint-Petersburg). (in Rus).

Chernikov 1960 - Chernikov, SS 1960, Pamjatniki arhitektury ojrat-kalmykov, Zapiski Kalmyckogo nauchno-issledovatel'skogo instituta, jazyka, literatury $i$ istorii, Jelista, Vyp. 1, S. 115-134. (Chernikov, SS 1960, Monuments of architecture of Oirat-Kalmyk, Notes of Kalmyk research Institute, language, literature and history, Jelista, Issue 1, P. 115-134). (in Rus).

Fal'k 1824 - Zapiski puteshestvija akademika Fal'ka. Polnoe sobranie uchenyh, puteshestvij po Rossii 1824, T. IV, Saint Petersburg. (Travel notes of academician Falk. Full collection of scientists, travel to Russia 1824, Vol. IV, Saint Petersburg). (in Rus).

Gennin 1837 - Gennin, V de 1837, Opisanie ural'skih i sibirskih zavodov, Moscow. (Gennin, V de 1837, Description of Ural and Siberian plants, Moscow). (in Rus).

Gmellin 1793 - Gmellin, IG 1793, Reise durch Siberien, Saint Petersburg. (Gmellin, IG 1793, Journey through Siberia, Saint Petersburg). (in Deutch).

Grum-Grzhimajlo 1926 - Grum-Grzhimajlo, GE 1926, Zapadnaja Mongolija i Urjanhajskij kraj, Leningrad. (Grum-Grzhimajlo, GE 1926, Western Mongolia and Uriankhayskiy edge, Leningrad). (in Rus).

Dopolnenija k aktam istoricheskim 1853 - Dopolnenija $k$ aktam istoricheskim, sobrannye $i$ izdannye arheograficheskoj komissiej 1853, T.V, Saint Petersburg. (Additions to historical acts, collected and published by the archaeographic Commission 1853, T.V, Saint Petersburg). (in Rus).

Nikitin 1906 - Nikitin, V 1906, Pamjatniki drevnosti Karkaralinskogo uezda, Zapiski Russkogo arheologicheskogo obshhestva, T. VIII, Vyp. I, T.2, Saint Petersburg. (Nikitin, V 1906, Monuments of antiquity karkarala County, Notes of the Russian archaeological society, Vol. VIII, Issue. I, T.2, Saint Petersburg). (in Rus).

Pallas 1786 - Pallas, PS 1786, Puteshestvie po raznym mestam Rossijskogo gosudarstva, Ch. II, Book 2 , Saint Petersburg. (Pallas, PS 1786, Travel to different places of the Russian state, Ch. II, Book 2, Saint Petersburg). (in Rus).

Pallas 1801 - Pallas, PS 1801, Sammlungen histouschen Nachrichten uber Mongolischen Volkershaften, T.11, Saint Petersburg. (Pallas, PS 1801, Collections histouschen news about Mongol Volker liable, T.11, Saint Petersburg). (in Deutch).

Pekarskij 1870 - Pekarskij, PP 1870, Istorija Akademii nauk, T. I, Saint Petersburg. (Pekarskij, PP 1870, History of the Academy of Sciences, T. I, Saint Petersburg). (in Rus).

Posol'stvo k zjungarskomu hanu 1892 - Posol'stvo k zjungarskomu hanu Hun Tajchzhi CjevanRabtanu kapitana ot artillerii Ivana Unkovskogo (1722-1724), Zapiski Imperatorskogo Russkogo geograficheskogo obshhestva po otdeleniju jetnografii 1892, T. X, Issue II, Saint Petersburg. (Khan Embassy to sugarcoma hung Taiji of Tsevan-Rabtan captain of artillery Ivan Unkovskii (1722-1724), Notes of the Imperial Russian geographical society in the Department of Ethnography 1892, T. X, Issue II, Saint Petersburg). (in Rus).

Puteshestvie cherez Sibir'1882 - Puteshestvie cherez Sibir' ot Tobol'ska do Nerchinska i granic Kitaja russkogo poslannika N. Spafarija v 1675 g, Zapiski Imperatorskogo Russkogo geograficheskogo obshhestva po otdeleniju jetnografii 1882, T.X, Issue I, Saint Petersburg. (Journey through Siberia from Tobolsk to Nerchinsk and the Chinese border the Russian envoy N. Spafary in 1675, Notes of the Imperial Russian geographical society in the Department of Ethnography 1882, T.X, Issue I, Saint Petersburg). (in Rus).

Radlov 1891 - Radlov, V 1891, Sibirskie drevnosti, T. I, Issue 3, Saint Petersburg. (Radlov, V 1891, Siberian antiquities, T. I, Issue 3, Saint Petersburg). (in Rus).

Remezov 1882 - Remezov, S 1882, Kratkaja sibirskaja letopis' (Kungurskaja), Saint Petersburg. (Remezov, S 1882, Short Siberian chronicle (Kungur), Saint Petersburg). (in Rus).

Ritter 1860 - Ritter, K 1860, Zemlevedenie Azii, T. III, Saint Petersburg. (Ritter, K 1860, landowning of Azia, T. III, Saint Petersburg). (in Rus).

Rygdylon 1952 - Rygdylon, JeR 1952, The Remains of the Mongolian inscription at the Bukhtarma cave, Jepigrafika Vostoka, Issue 7, P. 77-80. (Rygdylon, JeR 1952, Ostatki mongol'skoj nadpisi u Buhtarminskoj peshhery, Epigraphy of the East, Issue 7, P. 77-80). (in Rus).

Saharov 1849 - Saharov, N 1849, Skazanija russkogo naroda, T. II, Saint Petersburg. (Saharov, N 1849, Legends of the Russian people, T. II, Saint Petersburg). (in Rus).

Shastina 1958 - Shastina, NP 1958, Russko-mongol'skie posol'skie otnoshenija XVII veka, Moscow. (Shastina, NP 1958, Russian-Mongolian Embassy relations from the XVII century, Moscow). (in Rus).

Sievers 1796 - Sievers, V 1796, Sibirische Briefe, Saint Petersburg. (Sievers, V 1796, Siberian Letters, Saint Petersburg). (in Deutch).

Spasskij 1818 - Spasskij, Gl 1818, Drevnosti Sibiri, Sibirskij vestnik, Ch. III, Saint Petersburg (Spasskij, Gl 1818, Antiquities of Siberia, Siberian Bulletin, Ch. III, Saint Petersburg). (in Rus). 
Strahlenberg 1730 - Strahlenberg, FI 1730, Das Nord - und ostliche Theil von Europa und Asia. (Strahlenberg, FI 1730, The Northern and Eastern part of Europe and Asia). (in Deutch).

Tchichatcheff 1845 - Tchichatcheff, PA 1845, Voyage dans I'Altaj, Paris. (Tchichatcheff, PA 1845, Trip to Altaj, Paris). (in Franc).

Vitsen 1785 - Vitsen, N 1785, Noord en Oost Tarfarie, Amsterdam. (Vitsen, N 1785, North and East of Tarfarie, Amsterdam). (in NI).

Vlangeli 1853 - Vlangeli, 1853, Geograficheskie poezdki v vostochnuju chast' Kirgizskoj stepi, T. I, Saint Petersburg. (Vlangeli, 1853, Geographical trips to the Eastern part of the Kyrgyz steppe, T. I, Saint Petersburg). (in Rus). 